\title{
The Influence of Environmental Performance, Environmental Cost and ISO 14001 on Financial Performance in Non-Financial Companies Listed on the Indonesia Stock Exchange
}

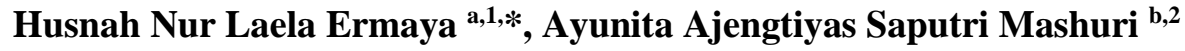 \\ ${ }^{\text {a }}$ Fakultas Ekonomi dan Bisnis, Universitas Pembangunan Nasional Veteran Jakarta \\ ${ }^{\mathrm{b}}$ Fakultas Ekonomi dan Bisnis, Universitas Pembangunan Nasional Veteran Jakarta \\ ${ }^{1}$ husnahnurlaela81@gmail.com *; ${ }^{2}$ ayunita.ajeng@gmail.com \\ * corresponding author
}

\section{ARTICLE INFO}

\section{Article History}

Received

Revised

Accepted

\section{Keywords}

Environmental Performance;

Environmental Cost;

ISO 14001;

Financial Performance

\section{ABSTRACT}

This study aims to determine the effect of Environmental Performance, Environmental Costs and ISO 14001 on Financial Performance. The independent variable in this study was Environmental Performance measured by using PROPER, Environmental Costs measured by environmental costs incurred by companies, ISO 14001 measured by a dummy with a weight of 1 for companies that have ISO 14001 certification and 0 for and vice versa. The population in this study are all non-financial companies listed on the Indonesia Stock Exchange (IDX) with an observation period of 3 years, 2016-2018, using a sampling method that is purposive sampling and the total sample obtained is 23 sample companies per year, 2 outlier samples, so that the total sample obtained in this study was 67 samples. The results of this study indicate that environmental performance has a significant positive effect on financial performance, environmental costs have a significant negative effect on financial performance, and ISO 14001 doesn't effect on financial performance.

\section{PENDAHULUAN}

Pada era globalisasi saat ini, isu lingkungan menjadi suatu masalah penting yang perlu diperhatikan. Hal tersebut tentunya menimbulkan berbagai tuntutan bagi perusahaan untuk lebih memperhatikan tanggung jawabnya atas keadaan lingkungan \& masyarakat sekitar. Para pelaku bisnis saat ini dituntut untuk dapat mengelola sumber daya yang mereka miliki agar dapat berjalan secara lebih efektif dan efisien. Hal ini berguna untuk menunjang apa yang telah menjadi tujuan utama perusahaan yaitu untuk meningkatkan laba perusahaan (Rizky, 2017). Tingkat laba yang terus meningkat mencapai keuntungan maksimum merupakan indikator yang baik untuk kinerja keuangan sebuah perusahaan, dimana kinerja keuangan diposisikan sebagai penentu sustainability perusahaan (Sueb dan Keraf, 2014). Sehubungan dengan hal tersebut, saat ini perusahaan tidak lagi hanya memperhatikan catatan atau laporan yang terkait dengan informasi keuangan saja (Single Bottom Line), melainkan juga harus memperhatikan aspek sosial dan lingkungan sekitarnya (Triple Bottom Line).

Prinsip memaksimalkan laba perusahaan guna mendapatkan keuntungan yang maksimal terkadang mengesampingkan manajemen lingkungan, kinerja lingkungan, atau bahkan konservasi lingkungan suatu perusahaan. Hal ini disebabkan karena perilaku eksploitatif yang ditunjukkan dalam pemanfaatan sumber daya alam dan kurangnya tanggungjawab terhadap lingkungan (fisik dan sosial) yang terkadang menyebabkan kurang terjalinnya hubungan sosial dengan masyarakat (Mardikanto, 2014).

Berbagai masalah lingkungan di Indonesia masih banyak terjadi dan harus ditindaklanjuti. Kasus pencemaran lingkungan yang terjadi di Perairan Pulau GAG, dimana pencemaran yang diakibatkan oleh limbah tambang nikel PT GAG anak perusahaan PT Antam Tbk ini membuat Perairan Pulau GAG menjadi berwarna coklat (Sindonews, 2018). Selain itu, pencemaran lingkungan yang terjadi di Desa Karanglo, Kabupaten Tuban, yang merupakan desa yang terletak di ring satu kawasan pertambangan milik PT. Semen Indonesia Tbk. Wahana Lingkungan Hidup Indonesia (Walhi) Jawa Timur menduga, aktivitas pertambangan semen di Tuban tersebut menjadi penyebab utama kematian beruntun warga di kawasan itu, kematian tersebut dikarenakan pencemaran udara di sekitar kawasan tambang semen cukup tinggi. Selain pencemaran udara, pencemaran air juga sudah dirasakan oleh masyarakat, seperti perubahan kondisi air sumur milik warga yang menjadi asin (Mongabay, 2016). Greenpeace Indonesia merilis hasil investigasi terkait aktivitas 
pertambangan batubara oleh PT Indominco Mandiri, anak perusahaan PT Indo Tambangraya Megah Tbk. di Provinsi Kalimantan Timur yang merusak bentang alam dan mengganggu kualitas air tanah. Lahan yang semulanya merupakan hutan dan lahan pangan menjadi danau-danau bekas tambang yang terbengkalai dan tanah gersang, sehingga masyarakat mengeluhkan kelangkaan air (greeners, 2016).

Pemerintah melalui Kementrian Lingkungan Hidup membentuk Program Penilaian Peringkat Kinerja Perusahaan dalam Pengelolaan Lingkungan Hidup (PROPER) yang telah dilaksanakan mulai tahun 2002 dibidang pengendalian dampak lingkungan untuk meningkatkan peran perusahaan dalam program pelestarian lingkungan hidup. Berdasarkan hasil PROPER pada tahun 2015, sebanyak 21 perusahaan masuk dalam peringkat Hitam. Perusahaan tersebut terdiri dari 7 rumah sakit, 3 pengolahan ikan dan masing-masing 1 perusahaan bergerak di bidang perhotelan, pabrik karet, pabrik kertas, industri komponen otomotif, makanan dan minuman, pengecoran logam, pengolahan limbah B3, peralatan rumah tangga, dan sawit (wartaekonomi, 2015).

Pengungkapan kinerja lingkungan sebagai tanggungjawab sosial perusahaan dapat mempengaruhi kinerja keuangan. Perusahaan yang memperhatikan tanggungjawab terhadap lingkungan baik sosial maupun fisik dimana perusahaan tersebut berada, akan memberikan respon positif bagi para investor dan calon investor dalam memandang perusahaan terlebih lagi jika perusahaan tersebut memiliki peringkat yang baik dalam program kepedulian lingkungan hidup (Andayani, 2015). Respon tersebut dapat berupa kepercayaan investor dalam menanamkan modal mereka pada perusahaan melalui saham ataupun investasi lainnya. Meningkatnya kepercayaan para investor dalam menanamkan modal mereka pada perusahaan akan mendorong meningkatnya return nilai perusahaan yang diwakili oleh return on asset (ROA) (Andayani, 2015). Hasil penelitian Fitriani (2013), dan Whino (2014) menjelaskan bahwa kinerja lingkungan berpengaruh terhadap kinerja keuangan perusahaan.

Dalam menjalankan tanggung jawab sosial perusahaan di bidang lingkungan, maka perusahaan juga membutuhkan biaya dalam aktivitas yang dilakukan. Biaya yang timbul dalam melakukan aktifitas lingkungan ini disebut biaya lingkungan. Biaya lingkungan meliputi biaya-biaya internal dan eksternal yang berhubungan dengan kerusakan lingkungan dan upaya perlindungan yang dilakukan oleh suatu perusahaan (Ikhsan,2004 :104). Biaya lingkungan yang terjadi pada perusahaan dalam kegiatan usahanya, merupakan konsekuensi dari upaya perusahaan dalam memelihara lingkungan (Bangun dan Sunarni, 2013).

Alokasi biaya lingkungan diperusahaan secara jangka pendek memang sepertinya merupakan beban dan mengurangi profit bagi perusahaan akan tetapi untuk periode jangka panjang dapat menjadi penghematan energi, kerusakan lingkungan termonitor dan terkendali, perbaikan lingkungan yang berkesinambungan, produktivitas perusahaan meningkat, citra positif perusahaan ramah lingkungan dan akhirnya dapat meningkatkan Laba Per Saham perusahaan (Dewi, 2014). Hasil peneliltian Irfan dkk (2017) dan Acti Ifrueze (2013) yang menjelaskan bahwa environmental cost berpengaruh signifikan negatif terhadap economic performance. Hadi (2011) yang menyatakan biaya sosial tidak berpengaruh terhadap kinerja keuangan perusahaan. Hal ini dikarenakan tanggungjawab sosial perusahaan melalui biaya sosial lebih dilihat dari perspektif dan motif manajemen, dan kurang memperhitungkan kebutuhan stakeholders, terutama stakeholders eksternal (masyarakat).

Untuk dapat melaksanakan tanggung jawab lingkungannya, perusahaan harus melakukan perbaikan atas pengelolaan dan pengendalian dampak lingkungannya secara berkelanjutan, dalam hal tersebut, perusahaan dapat menggunakan perangkat pengelolaan lingkungan, yaitu dengan Sistem Manajemen Lingkungan ISO 14001 yang merupakan standar yang diakui secara internasional untuk pengembangan sistem manajemen lingkungan yang efektif (Ong et al., 2016). International Organization for Standarization (ISO) adalah organisasi yang mengeluarkan ISO 14001 tentang standar internasional mengenai Environmental Management System (SML) merupakan dasar konsep ISO 14000, yaitu suatu sistem untuk mencapai pengelolaan lingkungan yang baik dan bersifat sukarela (Ramadhanti, 2013).

Permasalahan yang ada kini yaitu tidak semua perusahaan mau dan mampu untuk menerapkan SML ISO 14001. Selain karena bersifat sukarela, beberapa penelitian mengungkapkan bahwa sertifikasi SML ISO 14001 membutuhkan biaya yang besar bergantung pada karakteristik dan fasilitas masing- masing perusahaan yang mencakup biaya investasi dan biaya audit rutin (Aprilasani, 2017). Keuntungan ekonomi yang dapat diperoleh dari SML ISO 14001 antara lain memperbaiki kinerja lingkungan secara keseluruhan, menghasilkan suatu kerangka kerja dalam upaya untuk pencegahan polusi, meningkatkan efisiensi dan penghematan biaya potensial, dan meningkatkan citra perusahaan (Sueb dan Keraf, 2014).

Husnah Nur Laela Ermaya, et.al (The Influence of Environmental Performance, Environmental ...) 
Perusahaan yang menerapkan ISO 14001 dapat meningkatkan kinerja keuangan perusahaan (ROA dan ROE). Hal ini dikarenakan banyak investor percaya bahwa perusahaan yang memberi perhatian khusus terhadap lingkungan akan lebih berkelanjutan daripada yang tidak. Karena itu, investor juga akan memilih berinvestasi di green companies dalam jangka panjang (Tze San Ong et al, 2016). Namun hasil penelitian ini berbeda dengan hasil penelitian yang dilakukan oleh Hazudin et al (2015), Andayani (2015), dan Aprilasani et al (2017) yang menjelaskan bahwa tidak adanya pengaruh ISO 14001 terhadap kinerja keuangan perusahaan.

Berdasarkan hasil penelitian sebelumnya yang berbeda, serta bukti yang belum kuat, maka hal ini memotivasi peneliti untuk dapat meneliti lebih lanjut mengenai Environmental Performance, Environmental Cost, ISO 14001 dan Financial Performance pada seluruh perusahaan non keuangan yang terdaftar di Bursa Efek Indonesia dimana dari hasil penelitian sebelumnya hanya berfokus pada perusahaan manufaktur. Dari latar belakang permasalahan yang telah diuraikan diatas, maka rumusan masalah dalam penelitian ini adalah; 1) Apakah Environmental Performance berpengaruh signifikan terhadap Financial Performance? 2) Apakah Environmental Cost berpengaruh signifikan terhadap Financial Performance? 3) Apakah ISO 140001 berpengaruh signifikan terhadap Financial Performance?. Tujuan dari penelitian ini adalah untuk menguji secara empiris pengaruh dari environmental performance, environmental cost dan ISO 140001 terhadap financial performance.

\section{LANDASAN TEORI}

\section{Teori Legitimasi}

Suatu kondisi atau status yang ada ketika entitas memberikan keharmonisan pada kelompok sosial dimana entitas merupakan bagian dari kelompok sosial tersebut (Dowling \& Pfeffer, 1975). Ketika sebuah ketidakharmonisan terjadi antara sebuah entitas dan kelompok sosial yang ada disekitarnya maka entitas tersebut akan mendapatkan sebuah ancaman legitimasi. Teori legitimasi memiliki kelebihan dibandingkan teori lain karena teori ini mengungkapkan strategi yang dapat diadopsi perusahaan untuk membuktikan keberadaan mereka yang mungkin diuji secara empiris (Gray et al, 1995). Organisasi bukan hanya harus terlihat memperhatikan hak-hak investor namun secara umum juga harus memperhatikan hak-hak publik (Deegan dan Rankin, 1996). Teori legitimasi menegaskan bahwa perusahaan terus berupaya untuk memastikan bahwa mereka beroperasi dalam bingkai dan norma yang ada dalam masyarakat atau lingkungan dimana perusahaan berada, dimana mereka berusaha untuk memastikan bahwa aktivitas perusahaan diterima oleh pihak luar sebagai suatu yang "sah" (Deegan, 2004). Donovan (2002) berpendapat bahwa legitimasi suatu organisasi dapat dilihat sebagai sesuatu yang diberikan masyarakat kepada perusahaan dan sesuatu yang diinginkan atau dicari dari masyarakat. Dengan demikian legitimasi memiliki manfaat untuk mendukung keberlangsungan hidup suatu perusahaan (going concern).

\section{Teori Stakeholder}

Konsep stakeholder pertama kali dikembangkan oleh Freeman untuk menjelaskan tingkah laku perusahaan (corporate behaviour) dan kinerja sosial (Ghomi dan Leung, 2013). Stakeholder sebagai kelompok atau individu yang dapat memengaruhi atau dipengaruhi oleh suatu pencapaian tujuan tertentu (Freeman,1984:46). Teori stakeholder digunakan sebagai dasar untuk menganalisis kelompok kepada siapa perusahaan harus bertanggungjawab. Teori ini menyatakan bahwa perusahaan membutuhkan dukungan dari stakeholder untuk melanjutkan eksistensinya (Gray et al, 1995). Keberadaan korporasi sebagai suatu entitas bisnis di suatu tempat tidak hanya berinteraksi langsung dengan pemerintah selaku pemberi otoritas formal, tapi juga dengan banyak pihak yang menjadi stakeholder-nya, termasuk masyarakat setempat (Lako, 2011: 98).

\section{Financial Performance}

Kinerja keuangan adalah kemampuan perusahaan dalam mengelola dan mengendalikan sumber daya yang dimilikinya (Ikatan Akuntan Indonesia, 2018). Kinerja keuangan merupakan salah satu tolak ukur keberhasilan perusahaan dari sisi finansial (Damanik dan Yadnyana, 2017). Kinerja keuangan perusahaan dapat diukur melalui laporan keuangan yang dikeluarkan secara periodik yang dapat memberikan suatu gambaran tentang posisi keuangan, karena laporan keuangan melaporkan aktivitas yang sudah dilakukan perusahaan dalam suatu periode. Kinerja keuangan dapat diukur dengan membandingkan angka-angka yang ada pada satu komponen dengan komponen lainnya di dalam laporan keuangan. Perbandingan tersebut 
merupakan analisis laporan keuangan.

\section{Environmental Performance}

Environmental Performance adalah kinerja perusahaan dalam menciptakan lingkungan sekitar perusahaan menjadi lebih baik (green) (Suratno dkk, 2007). Environmental Performance merupakan upaya perusahaan yang perlu ditunjukkan kepada para stakeholder perusahaan khususnya masyarakat dan lingkungan sebagai bentuk kepedulian dan tanggungjawab perusahaan terhadap aspek lingkungan yang ditimbulkan oleh aktivitas perusahaan. Pelaku lingkungan yang baik percaya bahwa dengan mengungkapkan performance mereka berarti menggambarkan good news bagi pelaku pasar (Verrecchia, 1983). Sehingga, perusahaan dengan kinerja lingkungan yang baik akan mengungkapkan informasi kuantitas dan mutu lingkungan yang lebih dibandingkan dengan perusahaan yang kinerja lingkungannya buruk.

\section{Environmental Cost}

Environmental Cost merupakan biaya-biaya yang dikeluarkan oleh perusahaan yang berkaitan dengan kerusakan lingkungan yang ditimbulkan dan upaya perlindungan yang dilakukan. Salah satu alasan penting dalam mengatur biaya lingkungan secara hati-hati adalah karena biaya lingkungan dapat mempengaruhi kondisi perusahaan seperti biaya lainnya oleh karena itu harus diatur untuk meningkatkan profitabilitas perusahaan (Ikhsan,2009:115). Environmental Cost mencakup dari keseluruhan biaya-biaya paling nyata (seperti limbah buangan), untuk mengukur ketidakpastian, biaya lingkungan pada dasarnya berhubungan dengan produk, proses, sistem, atau fasilitas penting untuk pengambilan kepurusan manajemen yang baik (Rohelmy et al, 2015). Perusahaan menjelaskan environmental cost atau biaya lingkungan tergantung pada bagaimana perusahaan menggunakan informasi alokasi biaya, penganggaran, dan skala atau cakupan aplikasinya.

\section{ISO 14001}

International Organization for Standarization (ISO) adalah organisasi yang mengeluarkan ISO 14001 yang merupakan standar internasional mengenai Environmental Management System (SML). Menurut Kementrian Lingkungan Hidup, SML membantu organisasi dalam memperbaiki kinerja lingkungan melalui penggunaan sumber daya yang lebih efisien dan pengurangan limbah, sehingga mendapatkan keunggulan kompetitif dan kepercayaan pemangku kepentingan. ISO 14001 menetapkan kriteria untuk sistem manajemen lingkungan dan dapat disertifikasi. Hal tersebut merupakan kerangka kerja yang dapat diikuti oleh perusahaan atau organisasi untuk membentuk sistem manajemen lingkungan yang efektif. Dengan menerapkan ISO 14001, perusahaan dapat memberikan jaminan kepada manajemen perusahaan dan karyawan serta pemangku kepentingan eksternal bahwa dampak lingkungan sedang diukur dan ditingkatkan. Gavronski et al. (2008) menyatakan bahwa terdapat empat dimensi yang menandai manfaat dari sertifikasi ISO 14001: perubahan operasional; dampak keuangan; hubungan dengan pemangku kepentingan bisnis (pelanggan, pesaing, pemasok); dan hubungan dengan pemangku kepentingan masyarakat (pemerintah, masyarakat, dan LSM).

\section{Pengembangan Hipotesis}

Environmental performance adalah kinerja perusahaan dalam menciptakan lingkungan yang baik (green) (Andayani, 2015). Perusahaan dipandang sebagai organisasi yang harus conform dengan aturan masyarakat untuk menjamin social approval dan dapat terus eksis (Whino, 2014). Penelitian yang dilakukan Fitriani (2013) membuktikan bahwa PROPER yang digunakan sebagai alat ukur kinerja lingkungan perusahaan berpengaruh terhadap kinerja keuangan perusahaan, hal ini menunjukkan bahwa semakin baik kinerja lingkungan maka akan direspon positif oleh investor melalui fluktuasi harga saham perusahaan yang dapat meningkatkan kinerja keuangan perusahaan. Kinerja lingkungan berpengaruh positif dan signifikan terhadap kinerja keuangan karena perusahaan dengan kinerja lingkungan baik akan mendapat respon yang baik pula dari stakeholder dan berdampak pada peningkatan pendapatan perusahaan dalam jangka panjang (Djuitaningsih dan Ristiawati, 2011).

\section{H1: Environmental Performance berpengaruh signifikan terhadap Financial Performance}

Environmental Cost merupakan biaya yang dikeluarkan oleh perusahaan berhubungan dengan program perbaikan lingkungan akibat dari pencemaran lingkungan yang dilakukan oleh perusahaan secara sengaja ataupun tidak disengaja (Camilia, 2016). Biaya yang dialokasikan ke lingkungan alam merupakan investasi bagi perusahaan, perusahaan akan mendapat manfaat sosial dan ekonomi dalam jangka panjang 
(Dewi, 2014). Adanya penerapan anggaran biaya lingkungan akan berdampak pada produk yang sedang diproduksi dan dipasarkan. Salah satunya adalah image positif kepada para konsumen yang ingin membeli produk yang terbaik yaitu berkualitas, ramah lingkungan dan terjangkau. Hal ini akan berdampak pada peningkatan profitabilitas di sebuah industri (Rohelmy, 2015). Biaya lingkungan berpengaruh positif terhadap keunggulan kompetitif karena biaya lingkungan yang dikeluarkan perusahaan mampu meningkatkan reputasi perusahaan yang berpengaruh positif terhadap keunggulan kompetitif (Al Sharairi, 2005).

\section{H2: Environmental Cost berpengaruh signifikan terhadap Financial Performance}

Sistem Manajemen Lingkungan ISO 14001 (SML ISO-14001) merupakan suatu perangkat pengelolaan lingkungan yang bersifat sukarela (voluntary) bertujuan untuk secara berkelanjutan mencapai perbaikan pengelolaan dan pengendalian dampak lingkungan, dengan prinsip kerja yang mengutamakan pencegahan polusi, taat dengan peraturan dan perbaikan berkelanjutan. Elemen yang ada di dalam ISO 14001 mempunyai hubungan satu dengan yang lainnya dan saling mempengaruhi terutama dalam penerapan dan operasi serta pengkajian manajamen (Sueb dan Keraf, 2012). Hal tersebut yang pengimplementasiannya di dalam perusahaan memiliki pengaruh positif terhadap pencapaian kinerja keuangan pada perusahaan yang sudah memperoleh sertifikat ISO 14001. Hasil penelitian Tze San Ong et al (2016) menunjukkan bahwa perusahaan yang menerapkan ISO 14001 dapat meningkatkan kinerja keuangan perusahaan (ROA dan ROE). Hal ini dikarenakan banyak investor percaya bahwa perusahaan yang memberi perhatian khusus terhadap lingkungan akan lebih berkelanjutan daripada yang tidak. Karena itu, investor juga akan memilih berinvestasi di green companies dalam jangka panjang. Salah satu indikasi green companies adalah apakah mereka telah mengadopsi standar ISO 14001 atau tidak.

H3: ISO 14001 berpengaruh signifikan terhadap Financial Performance

\section{METODE PENELITIAN}

Metode penelitian yang digunakan dalam penelitian ini adalah metode kuantitatif. Populasi yang digunakan dalam penelitian ini adalah seluruh perusahaan non keuangan yang terdaftar di BEI pada periode 2016-2018, dengan metode pengambilan sampel menggunakan Purposive Sampling serta beberapa kriteria yang telah ditentukan. Teknik analisis data yang digunakan dalam penelitian ini adalah uji statistik deskriptif, uji asumsi klasik, dan uji hipotesis dengan menggunakan analisis regresi berganda. Analisis ini dilakukan untuk mengetahui kekuatan dan arah hubungan antara variabel independen dengan variabel dependen.

\section{Pengukuran Variabel Variabel Dependen}

Pengukuran Financial Performance dalam penelitian ini dengan menggunakan Return On Asset (ROA) seperti yang dilakukan Brigham and Houston (2006) dengan rumus sebagai berikut ini:

$$
\text { ROA }=\frac{\text { LabaBersih }}{\text { Total Aset }}
$$

\section{Variabel Independen}

\section{Environmental Performance (X1)}

Variabel ini diproksikan dengan menggunakan hasil pemeringkatan kinerja perusahaan dalam pengelolaan lingkungan hidup atau PROPER periode 2016-2018 yang dilakukan oleh Kementerian Negara Lingkungan Hidup. Peringkat PROPER dikategorikam dalam lima (5) warna dan disetiap warnanya diberikan skor penilaian secara berturut-turut sesuai warna, yaitu sebagai berikut:

Tabel 1. Peringkat Proper

\begin{tabular}{llll}
\hline No & Warna & Keterangan & Skor \\
\hline 1 & Emas & Sangat sangat baik & 5 \\
\hline 2 & Hijau & Sangat baik & 4 \\
\hline 3 & Biru & Baik & 3 \\
\hline 4 & Merah & Buruk & 2 \\
\hline 5 & Hitam & Sangat buruk & 1 \\
\hline
\end{tabular}

Sumber : data sekunder yang telah diolah

Husnah Nur Laela Ermaya, et.al (The Influence of Environmental Performance, Environmental ...) 


\section{Environmental Cost (X2)}

Menurut penelitian sebelumnya yang dilakukan oleh Fitriani (2013), pengukuran environmental cost adalah sebagai berikut:

\section{ISO $14001(\mathrm{X3})$}

$$
\text { Environmental Cost }=\frac{\text { Biaya yang dikeluarkan untuk } \operatorname{CSR}}{\text { Laba Bersih }}
$$

Penelitian ini menggunakan sertifikasi ISO 14001 yang merupakan pengaplikasian sistem manajemen lingkungan hidup suatu perusahaan. Pengukuran pada variabel ini adalah dengan menggunakan dummy dengan bobot 1 untuk perusahaan yang memiliki sertifikasi ISO 14001 dan 0 untuk perusahaan yang tidak memilikinya (Sueb dan Keraf, 2014).

\section{Model Regresi}

Persamaan regresi linear berganda dalam penelitian ini dapat dinyatakan sebagai berikut:

$\mathrm{Y}=\boldsymbol{\alpha}+\boldsymbol{\beta 1} \mathrm{X} 1+\boldsymbol{\beta} 2 \mathrm{X} 2+\beta 3 \mathrm{X3}+\varepsilon$

Keterangan :

$\mathrm{Y} \quad=$ Financial Performance

a $\quad$ Konstanta

$\mathrm{X} 1=$ Environmental Performance

$\mathrm{X} 2=$ Environmental Cost

$\mathrm{X} 3=$ ISO 140001

\section{HASIL DAN DISKUSI}

Berikut adalah hasil pemilihan sampel yang telah ditentukan dalam penelitian ini.

Tabel 2. Sampel Berdasarkan Kriteria

\begin{tabular}{|c|l|c|}
\hline No. & \multicolumn{1}{|c|}{ Keterangan Perusahaan } & Jumlah \\
\hline 1. & Jumlah Perusahaan Non-Keuangan yang listing di BEI Indonesia & 557 \\
\hline 2. & $\begin{array}{l}\text { Jumlah Perusahaan Non-Keuangan yang mengalami delisting dan tidak } \\
\text { menerbitkan Sustainability Report }\end{array}$ & $(506)$ \\
\hline 3. & Jumlah Perusahaan yang tidak mengikuti PROPER & $(1)$ \\
\hline 4. & Jumlah Perusahaan yang tidak memiliki data lengkap & $(27)$ \\
\hline 5. & Jumlah perusahaan yang menjadi sampel penelitian & 23 \\
\hline 6. & Jumlah periode penelitian & 3 \\
\hline 7. & Jumlah sampel penelitian sebelum outlier & 69 \\
\hline 8. & Sampel penelitian yang dikecualikan karena outlier & $(2)$ \\
\hline 9. & Jumlah sampel penelitian setelah outlier & 67 \\
\hline
\end{tabular}

Berdasarkan tabel 2 diatas, proses seleksi sampel yang dilakukan dengan kriteria yang telah ditentukan, maka diperoleh 23 perusahaan yang dijadikan sebagai sampel dengan 3 periode pengamatan penelitian. Karena terdapat beberapa data yang nilainya ekstrem dan tidak layak untuk diinterpretasikan, maka peneliti memutuskan untuk menghapus data yang berdistribusi tidak normal atau melakukan outlier, sehingga total sampel secara keseluruhan sebanyak 67 sampel.

\section{Tabel 3. Hasil Uji Model Regresi Berganda}

\begin{tabular}{|c|c|c|c|c|c|c|}
\hline & \multirow[t]{2}{*}{ Model } & \multicolumn{2}{|c|}{$\begin{array}{c}\text { Unstandardized } \\
\text { Coefficients }\end{array}$} & \multirow{2}{*}{$\begin{array}{c}\text { Standardized } \\
\text { Coefficients } \\
\text { Beta }\end{array}$} & \multirow[t]{2}{*}{$\mathbf{t}$} & \multirow[t]{2}{*}{ Sig } \\
\hline & & B & $\overline{\text { Std Error }}$ & & & \\
\hline \multirow[t]{4}{*}{1} & (constant) &,- 115 & ,038 & & $-3,017$ & ,004 \\
\hline & Env Perfm & ,042 & ,010 & ,457 & 4,081 & ,000 \\
\hline & Env Cost &,- 011 & ,004 &,- 338 & $-3,059$ & ,003 \\
\hline & ISO 14001 & ,010 & 014 & ,079 & ,709 & ,481 \\
\hline \multicolumn{2}{|c|}{ Adj $R^{2}$} & 25,6 & & & & \\
\hline
\end{tabular}


Berdasarkan tabel. 3 uji regresi di atas, maka diperoleh persamaan regresi berganda sebagai berikut : $\mathrm{FP}=-0,115+0,042 \mathrm{EP}-0,011 \mathrm{EC}+0,010$ ISO

Berdasarkan tabel 3 diatas, menunjukkan nilai koefisien regresi environmental performance sebesar 0,042 dengan nilai siginifikan sebesar 0,000 . Hal ini menunjukkan bahwa environmental performance berpengaruh signifikan positif terhadap financial performance. Nilai koefisien regresi untuk environmental cost memiliki nilai sebesar -0,011 dengan tingkat siginifikan sebesar 0,003 , sehingga dapat disimpulkan bahwa environmental cost berpengaruh signifikan negative terhadap environmental performance. Nilai koefisien regresi untuk ISO 14001 sebesar 0,010 dan tingkat signifikan sebesar 0,481, sehingga dapat disimpulkan bahwa ISO 14001 tidak berpengaruh terhadap financial performance.

Kegiatan perusahaan dalam bidang pelestarian lingkungan akan mendatangkan sejumlah keuntungan, diantaranya ketertarikan pemegang saham dan stakeholder terhadap keuntungan perusahaan akibat pengelolaan lingkungan yang bertanggungjawab (Pflieger et al, 2005). Pengungkapan kinerja lingkungan sebagai tanggungjawab sosial perusahaan dapat mempengaruhi kinerja keuangan. Sebab perusahaan yang memiliki kinerja lingkungan baik, secara tidak langsung memiliki suatu informasi sosial yang baik pula sehingga dapat meningkatkan nilai perusahaan (Bahri dan Cahyani, 2016). Environmental performance atau kinerja lingkungan yaitu suatu kinerja perusahaan yang peduli terhadap lingkungan sekitar. Di Indonesia, penerapan kinerja lingkungan perusahaan di fasilitasi dengan adanya Program Penilaian Peringkat Kinerja Perusahaan dalam Pengelolaan Lingkungan Hidup (PROPER).

Hasil penelitian ini menunjukkan bahwa, environmental performance berpengaruh signifikan positif terhadap financial performance. Environmental performance dapat menjadi bahan pertimbangan untuk melihat financial performance hal ini dikarenakan citra positif perusahaan dapat meningkatkan minat masyarakat dalam melakukan pembelian produk perusahaan yang akan membuat financial performance meningkat. Meningkatnya kepercayaan para investor dalam menanamkan modal mereka pada perusahaan akan mendorong meningkatnya return nilai perusahaan yang diwakili oleh return on asset (ROA) (Andayani, 2015). Penelitian yang dilakukan oleh Whino (2014) menjelaskan bahwa Environmental performance memiliki pengaruh signifikan positif terhadap kinerja keuangan. Sehingga dapat menyatakan bahwa Peringkat Kinerja Perusahaan dalam Pengelolaan Lingkungan (PROPER) yang dilakukan oleh pemerintah dalam hal ini Kementrian Lingkungan Hidup (KLH) dapat mempengaruhi minat stakeholder terutama para investor dan masyarakat. Hasil penelitian ini sejalan dengan penelitian Djuitaningsih dan Ristiawati (2011), yang menyatakan bahwa kinerja lingkungan berpengaruh positif dan signifikan terhadap kinerja keuangan karena perusahaan dengan kinerja lingkungan baik akan mendapat respon yang baik pula dari stakeholder dan berdampak pada peningkatan pendapatan perusahaan dalam jangka panjang. Perusahaan dengan tingkat pertumbuhan tinggi, kinerja lingkungan berpengaruh positif terhadap kinerja keuangan sedangkan pada perusahan dengan tingkat pertumbuhan rendah, kinerja lingkungan berpengaruh negatif terhadap kinerja keuangan. Hal ini karena perusahaan dengan tingkat pertumbuhan tinggi memiliki gaya manajemen yang lebih organik dan dapat mengambil keuntungan tambahan dengan berinvestasi melalui kinerja lingkungan (Darnall, 2005).

Dalam menjalankan tanggung jawab sosial perusahaan di bidang lingkungan, maka perusahaan akan melakukan beberapa aktifitas yang berhubungan dengan lingkungan. Dengan melakukan aktifitas tersebut maka perusahaan juga akan membutuhkan biaya. Biaya lingkungan adalah biaya yang dikeluarkan perusahaan berhubungan dengan kerusakan lingkungan yang ditimbulkan dan perlindungan yang dilakukan (Susenohaji, 2003). Hasil penelitian ini menunjukkan bahwa environmental cost berpengaruh signifikan terhadap financial performance. Dengan melakukan perbaikan kualitas lingkungan secara terus menerus, perusahaan dapat meningkatkan output yang bebas dari kerusakan, sehingga perusahaan dapat lebih memaksimalkan dalam meningkatkan laba. Hal ini menyebabkan biaya operasional perusahaan berkurang, dengan demikian laba yang diperoleh akan dapat lebih meningkat (Ikhsan 2009, hlm. 94). Berdasarkan teori legitimasi keberadaan suatu perusahaan akan memperoleh legitimasi jika mampu memenuhi harapan para stakeholders. Dengan demikian besarnya biaya lingkungan yang dialokasikan perusahaan dianggap ikut serta dalam perbaikan lingkungan sehingga mendapat respon positif dari stakeholders dan memperoleh legitimasi atau keberadaannya diakui oleh stakeholders. Respon positif tersebut akan memberikan dampak bagi peningkatan profitabilitas perusahaan melalui peningkatan return tahunan perusahaan. Hasil penelitian ini sejalan dengan penelitian Rohelmy (2015) dan Al Sharairi (2005) yang menyatakan bahwa biaya lingkungan berpengaruh terhadap kinerja keuangan. 
Permasalahan kerusakan lingkungan salah satunya disebabkan dari eksternalitas pada kegiatan ekonomi. Eksternalitas merupakan kondisi dimana kesejahteraan suatu individu/kelompok tidak hanya bergantung pada aktivitasnya namun dipengaruhi pula oleh aktivitas individu/kelompok lain. Eksternalitas negatif pada lingkungan alam dan lingkungan sosial sebagai dampak dari aktivitas industri, dapat menimbulkan market failure yang kemudian berdampak pada perekonomian (Tietenberg dan Lewis, 2011). Sistem Manajemen Lingkungan (SML) adalah bagian dari pengelolaan lingkungan internal dan eksternal (Hariadi, 2004). Permasalahan lingkungan memerlukan instrumen atau alat untuk mengelola permasalahan tersebut. International Organization for Standarization (ISO) adalah organisasi yang mengeluarkan ISO 14001 tentang standar internasional mengenai Environmental Management System (SML) merupakan dasar konsep ISO 14000, yaitu suatu sistem untuk mencapai pengelolaan lingkungan yang baik dan bersifat sukarela (Ramadhanti, 2013). Hasil penelitian ini menunjukkan bahwa ISO 14001 tidak berpengaruh terhadap Financial performance. ISO 14001 belum dapat mempengaruhi kinerja keuangan suatu perusahaan, hal ini dikarenakan public masih menilai bahwa sertifikasi ISO 14001 hanya sebagai bentuk kepedulian perusahaan terhadap masalah lingkungan dan belum memiliki manfaat ekonomis bagi mereka. ISO 14001 hanya menggambarkan reputasi baik perusahaan terhadap masalah lingkungan kepada publik, dan hal tersebut belum dinilai publik memiliki pengaruh terhadap kinerja keuangan perusahaan (Hazudin et al, 2015). Dibutuhkan waktu yang lebih lama, bahkan sampai dekade, untuk mengetahui pengaruh ISO 14001 terhadap kinerja keuangan dikarenakan optimalisasi sistem ISO 14001 lebih sulit dibandingkan sistem ISO lainnya (Aprilasani, 2017). Hasil penelitian ini sejalan dengan hasil penelitian Hazudin et al (2015), Andayani (2015), dan Aprilasani et al (2017) yang menjelaskan bahwa tidak adanya pengaruh ISO 14001 dengan kinerja keuangan perusahaan.

\section{KESIMPULAN, IMPLIKASI DAN KETERBATASAN PENELITIAN}

Penelitian ini dilakukan untuk menguji pengaruh dari environmental performance, environmental cost dan ISO 140001. Hasil penelitian ini menunjukkan bahwa environmental performance, environmental cost dan ISO 140001 hanya mampu mempengaruhi financial performance sebesar 25,6\%, sedangkan sisanya sebesar 74,4\% dipengaruhi oleh variabel-variabel lain diluar variabel yang digunakan. Dalam pengujian secara parsial, terdapat dua variabel yang berpengaruh terhadap financial performance yaitu environmental performance dan environmental cost sedangkan variabel ISO 140001 tidak memiliki pengaruh yang terhadap financial performance.

Berdasarkan kesimpulan diatas maka ada beberapa saran yang perlu diperhatikan, yaitu perlunya menambahkan variabel lain, menggunakan model penelitian lain seperti menambah variabel intervening, moderasi atau variabel kontrol, sehingga dapat menambah ragam dalam penelitian, memperluas periode pengamatan penelitian karena periode penelitian yang lebih panjang akan memberikan kemungkinan yang lebih besar untuk memperoleh hasil yang lebih mendekati kondisi sebenarnya.

\section{DAFTAR PUSTAKA}

Acti I, M.S., Lyndon M. E. \& Bingilar, P. F. (2013) 'The impact of environmental cost on coerporate performance : A study of oil companies in Nigeria Delta State of Nigeria', Journal of Buisness \& Management, Vol.2, No.2, hlm. 1-10.

Andayani, Rezin. 2015. Hubungan Antara Iso 14001, Environmental performance dan Environmental disclosure Terhadap Economic Performance. Jurnal Akuntansi dan Sistem Teknologi Informasi Vol. 11 No 2 September 2015.

Aprilasani, Zeffa. 2017. Kajian Penerapan Sistem Manajemen Lingkungan ISO 14001 terhadap Kinerja Perusahaan (Studi pada Perusahaan yang Terdaftar di Bursa Efek Indonesia. [Tesis] Jakarta: Program Studi Ilmu Lingkungan, Sekolah Ilmu Lingkungan, Universitas Indonesia.

Bangun, Rilen Ninda, dan Ch. Wiwik Sunarni. Pelaporan Biaya Lingkungan Dan Penilaian Kinerja Lingkungan (Studi Kasus Pada PT Tangjungenim Lestari Pulp And Paper). Jurnal Ilmiah Akuntansi: Universitas Atmajaya Yogyakarta. 2013.

Brigham, Eugene F. dan Houston, Joul F. 2006. Fundamentals of Financial Management, Dasar- dasar Manajemen Keuangan. Jakarta : Salemba Empat.

Camilia, Ica. 2016. Pengaruh Kinerja Lingkungan Dan Biaya Lingkungan Terhadap Kinerja Keuangan Husnah Nur Laela Ermaya, et.al (The Influence of Environmental Performance, Environmental ...) 
Perusahaan Manufaktur. Artikel Ilmiah Stie Perbanas Surabaya.

Damanik, I Gst. Agung Bagus Adhi dan I Ketut Yadnyana. 2017. Pengaruh Kinerja Lingkungan Pada Kinerja Keuangan Dengan Pengungkapan Corporate Social Responsibility Sebagai Variabel Intervening. E-Jurnal Akuntansi Universitas Udayana Vol. 20 Nomor 1 Juli 2017.

Deegan, C. (2002). The legitimising effect of social and environmental disclosures - a theoretical foundation. Accounting, Auditing \& Accountability Journal 15 (3): 282-311.

Deegan, Craig dan Michaela Rankin. 1996. "The Materiality of Environmental Information to Users of Annual Report". Accounting, Auditing and Accountibility Journal, Vol. 10, No. 4, Hal. 562- 58

Dewi, Kartika. 2014. Analisa Environmental Cost Pada Perusahaan Non-Keuangan Yang Terdaftar Di Bursa Efek Indonesia Periode 2011, 2012 Dan 2013. Binus Business Review, Vol. 5 No. 2

November 2014, 615-625.

Djuitaningsih, Tita dan Erista Eka Ristiawati. 2015. Pengaruh Kinerja Lingkungan Dan Kepemilikan Asing Terhadap Kinerja Finansial Perusahaan. Jurnal Akuntansi Universitas Jember,Vol. 9, No. 2, mar. 2015. ISSN 2460-0377.

Donnovan, O. Garry. (2002). Enviromental Disclosure in The Annual Report: Extending The Applicability and Predictive Power of Legitimacy Theory, Accounting, Auditing \& Accountability Journal, Volume 15 Issue 3: 344-371.

Dowling, J. and Pfeffer, J. (1975). Organizational legitimacy: social values and organizational behaviour. Pacific Sociological Review, 18 (1): 122-36.

Fahmi, I. (2014). Analisis Laporan Keuangan, Bandung: Alfabeta.

Fitriani, Anis. 2012. Pengaruh Kinerja Lingkungan dan Biaya Lingkungan Terhadap Kinerja Keuangan Pada BUMN. Jurnal Ilmu Manajemen. Volume 1 Nomor 1 Januari 2013.

Freeman, Edward R. (1984). Strategic Management: Stakeholder Approach, Marshfield: Pitmen Publishing Inc.

Ghozali, I., (2018). Aplikasi Analisis Multivariate dengan Program IBM SPSS 25, Edisi 9, Semarang: Badan Penerbit Universitas Diponegoro.

Gray, R., Kouhly, R. and Lavers, S. (1995a). Corporate Social and Enviromental Reporting: A Review of The Literature and A Longitudinal Study of UK Disclosure. Accounting, Auditing \& Accountability Journal, Volume 8 Issue 2: 47-77.

Ghomi Z.B., \& Leung, P. (2013). An empirical analysis of the determinants of greenhouse gas voluntary disclosure in australian, Sciedu Press, vol.2, no.1.

Hadi, N. (2011). Corporate Social Responsibility. Yogyakarta: Graha Ilmu

Hazudin, Siti Fahazarina, Siti Aishah Mohamad, Ilyani Azet, Roazain Daud, dan Halil Paino. ISO 14001 and financial performance: is the accreditation financially worth it for malaysian firms. Procedia Economics and Finance 31, 56 - 61. 2015.

Ikatan Akuntansi Indonesia (IAI). 2009. Pernyataan standar akuntansi keuangan. (PSAK) no 1: penyajian laporan keuangan. Jakarta: IAI.

Ikhsan, A. (2009). Akuntansi Manajemen Lingkungan. Edisi Pertama. Yogyakarta: Graha Ilmu.

Irfansyah, Ermaya, H.N.L. dan Septyan, K. (2018). 'The Influence Of Environmental Performance, Environmental Disclosure And Environmental Cost On Economic Performance'. Economics and Accounting Journal, Vol. 1, No. 2. pp. 87-94.

Isnanto, B.A. (2017). Limbah Busuk Cemari Lingkungan, PT RUM di Sukoharjo Akui Kesalahan. detiknews. Diakses 03 Agustus 2018, dari https://news.detik.com/berita-jawa-tengah/d3701376/limbah-busuk-cemari-lingkungan-pt-rum-di-sukoharjo-akui-kesalahan

Kosasih, D. (2016). Greenpeace Rilis Kerusakan Lingkungan Akibat Tambang di Kalimantan Timur. Diakses 03 Agustus 2018, dari https://www.greeners.co/berita/greenpeace-rilis-kerusakan- lingkungan-akibat- 
tambang-di-kalimantan-timur/.

Lako, A. (2011). Dekonstruksi CSR dan reformasi paradigma bisnis dan akuntansi : Erlangga

Mardikanto, Totok. 2014. CSR Corporate Social Responsibility (Tangung Jawab Sosial Korporasi). Bandung: Alfabeta.

Ong, Tze San, Boon Heng Teh, Sin Huei Ng, dan Wei Ni Soh. 2016. Environmental Management System and Financial Performance. Institutions and Economies Vol. 8, No. 2, April 2016.

Ramadhanti, Fadhlillah. 2013. Kajian Sistem Manajemen Lingkungan ISO 14001: 2004 Pada Pt Coca Cola Bottling Plant Amatil Indonesia Cibitung. E-Jurnal IPB.

Rizky, Ryan. 2017. Pengaruh Environmental Performance, Environmental Cost Dan Csr Disclosure Terhadap Financial Performance. E-jurnal Universitas Dinus Semarang.

Rohelmy, Faishal Agung, Zahroh ZA, dan R. Rustam Hidayat. 2015. Efektivitas Penerapan Biaya Lingkungan Dalam Upaya Meminimalkan Dampak Lingkungan (Studi Pada Pt. Emdeki Utama). Jurnal Administrasi Bisnis (JAB)| Vol. 2 No. 2 Februari 2015.

Sharairi, Al dan Jamal Adel. 2005. The Impact of Environmental costs on the Competitive Advantage of Pharmaceutical Companies in Jordan. Middle Eastern Finance and Economics, ISSN: 1450- 2889 Issue 15 (2011).

Sueb, Memed dan Maria Nety Indramayu Keraf. 2012. Relasi Sistem Manajemen Lingkungan Iso 14001 Dan Kinerja Keuangan. Jurnal Dinamika Manajemen. Vol. 3, No. 1.

Suratno, Darsono, dan Siti Mutmainah. 2007. Pengaruh Environmental Performance Terhadap Environmental Disclosure dan Economic Performance (Studi Empiris pada Perusahaan Manufaktur yang terdaftar di BEJ Periode 2001-2004). The Indonesian Journal of Accounting Research. Vol. 10 No. 2.

Suripatty, C.A. (2018). Viral di Medsos, Foto-foto Perairan di Raja Ampat Diduga Tercemar Limbah Tambang. Sindonews. Diakses 03 Agustus 2018, dari https://daerah.sindonews.com/read/1303837/174/viral-di-medsos-foto-foto-perairan-di-raja- ampatdiduga-tercemar-limbah-tambang-1525703444.

Verrechia, R. (1983). Discretionary disclosure. Journal of Accounting and Economics, Issue 5: 179- 194.

Walhi. Ancaman kerusakan lingkungan hidup tambang pasir laut: Kasus Kab. Takalar, Sulwaesi Selatan. https://www.walhi.or.id.

Wartaekonomi. (2015). 21 Perusahaan Masuk Peringkat Hitam Penilaian Proper. Diakses 03 Agustus 2018, dari https://www.wartaekonomi.co.id/read80821/21-perusahaan-masuk- peringkat-hitam-penilaianproper.html.

Whino, Sekar Prasetyaning Tunggal dan Fachrurrozie. 2014. Pengaruh Environmental performance, Environmental cost dan CSR Disclosure Terhadap Financial Performance. Accounting Analysis Journal. Vol. 3, No. 1. 